\title{
THE FEMALE BODY AND THE CANNIBALISTIC REDEMPTION IN THE EDIBLE WOMAN: THE GROTESQUE IN MARGARET ATWOOD
}

RESUMO:

Este artigo estuda os aspectos grotescos da obra A mulher comestível de Margaret Atwood, enfocando o contraste de estereótipos de perfeição e imperfeição, regras de comportamento, e a luta de uma protagonista que rejeita os valores ditos normais de conduta feminina.

PALAVRAS-CHAVE: grotesco, literatura canadense, estudos de gênero.

Margaret Atwood, a renowned Canadian writer, poet, and literary critic, published her first novel, The Edible Woman, in 1969. This novel criticizes female victimization in a society that demands passivity from women. The Edible Woman has proven to be a fertile ground for studies about the grotesque, because it portrays the metamorphoses of a female protagonist who defies the prevailing norms of patriarchy, and it culminates in a symbolic act of cannibalism. Such an act frees her from being a victim in a consumerist society, in which women often acquire an infantilized, doll-like figure. Rebelling from such values that compare the female protagonist to prey and men to hunters, The Edible Woman demonstrates an alternative way out of male domination, which is the refusal of being a victim. Changing from victimization to confrontation, the protagonist finds a way to free herself from the straightjacket of an artificial construction of roles of female normality.

One of the main problems when analyzing the grotesque in a work, whether in art or literature, is identifying its grotesque aspects. Most scholars agree that

* Mestre em Letras: Estudos Literários (Ārea de concentração: Literaturas de Expressão Inglesa), 2003. 


\section{EMTESE}

Belo Horizonte, v. 8, p. I-243, dez. 2004

it is very hard to define the grotesque, because its notion is connected with conceptions of time, space and culture. Indeed, despite the difficulty in defining the grotesque, most scholars agree that the grotesque can be identified as something that defies a prevailing norm; and that it is necessary to establish the contrasts between the elements that oppose each other in the narrative, and to frame the work in question within its time, space and culture. Wolfgang Kayser believes that the grotesque is a "estranged world" in which the beholder does not identify the piece of art as something from the world of "normality." The beholder's understanding of the work in question as grotesque involves a repulsive response that evokes a mixture of feelings such as laughter, fascination and disgust. Indeed, Kayser defends the idea that it is this power that the grotesque has to affect people and bring out different responses that is most significant for the study of the grotesque in art and literature (184). James Luther Adams and Wilson Yates see Kayser's theory as a positive one, in which the beholder, despite experiencing at first glance something "negative, strange, and sinister," has the power to respond to such a menacing image, subduing and challenging it (19).

Mikhail Bakhtin's theory of the grotesque revolves around the carnival theory in which people participate in the transformation of a dogmatized and standardized world into a new one, which reverts the stratification of power. This destruction of prevailing truths of normality in order to reconstruct another realm of possibilities is what makes carnival manifestations of the grotesque in art so important, because, as Adams and Yates explain, such destruction turns the hierarchically constructed world upside down and provides people with an experience of equality, democracy, and a sense of the social world (Adams and Yates 23). For Bakhtin, the grotesque, whether in carnival or in other art manifestations, breaks down the hierarchical structure of what is socially seen as normal, leading people to question standardized roles of human behavior (9).

Like Kayser, Geoffrey Harpham also mentions that the beholder needs to have a repulsive response when confronting the grotesque, believing that the grotesque, whether in art or literature, "is a sphinx who dies once the riddle is solved" (46). The beholder extracts meaning from the grotesque, transforming it from something threatening into something acceptable to his/her concepts of normality. 
When facing the grotesque, the beholder has to act like 0edipus who solves the riddle and defeats the monster, bringing logic to the sphinx's grotesque riddle.

Collaborating in the development of studies on the grotesque in art and literature, Margaret Miles and Mary Russo believe that the grotesque is a device for questioning the role models of perfection that are informed by patriarchal cultures. Women who defy the status quo of power are likely to be seen as a threat, as subversive elements that corrupt what is taken for granted as normal in society. For Miles and Russo, such female protagonists who are seen as grotesque, due to their rebellious behavior and/or their imperfect bodies, actually use their grotesque characteristics to demand citizenship in a society in which there is no room for those who do not accept the pre-established rules of male and female normality. Aware of the constraints that are imposed upon the female body and behavior, Atwood criticizes such values of female perfection that are imposed upon women by patriarchal cultures in The Edible Woman.

Miles grounds her theory mostly in Harpham's studies on the grotesque and claims that, despite the fact that defining the grotesque is problematic, the concept does have a positive meaning because it implies discovery. Miles agrees with Harpham when he states that disorder is the price one has to pay for the enlargement of the mind (Harpham 191). She agrees that the grotesque is difficult to define with precision, but she supports the idea that it can be characterized. At the moment Miles identifies a way to characterize the grotesque, she adds an important innovation to grotesque theory, which establishes new grounds upon which scholars can analyze works of art and literature. The characterizations of the grotesque that Miles has accomplished are subdivided into the following categories: caricature, inversion, and hybridization (Miles 96). Al1 three such characterizations are part of Margaret Atwood's narratives but, in the case of The Edible Woman, caricature and inversion are the categories most employed by the author. Atwood grounds the grotesque in The Edible Woman mainly on the inversions of both traditional values and of male and female behavior.

In Miles' point of view, each of these characterizations has a specific connection to women, to their bodies and to their behavior. What she considers paramount to observe is that "the twentieth-century analyses of the grotesque - 


\section{EMTESE}

Belo Horizonte, v. 8, p. I-243, dez. 2004

Kayser, Bakhtin, Harpham - fail to notice the gender assumptions imbedded in grotesque art and literature, with the effect that they ignore a structural feature of this genre" (96). She claims that the affiliation of the female body with the grotesque is grounded on the assumption that the male body is the perfectly formed, complete, and therefore normative body. Diverging from this concept of male perfection, al1 women's bodies incorporate parts (breasts, uterus, and vagina) - and processes (menstruation and pregnancy) - that are different from the norm established by the male gaze and are, therefore, grotesque (96).

Mary Russo has contributed to studies on the grotesque by combining Bakhtin's and Harpham's theories of the carnival grotesque with the feminist studies that put the female body in evidence. The starting point of Russo's analysis of the female grotesque comes from what she calls a "matronizing phrase" that some women direct toward other women which is the belief that: "She [the other woman] is making a spectacle out of herself" (213). By not following standardized models of behavior when appearing in public in Western cultures, some women would be seen, not only by men but by some women too, as "spectacle women" whose behavior and appearance are not considered normal but rather grotesque.

I understand the female situation that Russo mentions to be a patriarchal device to control women in the public sphere, in which they actually have to play roles designed by the system. Such rules and impositions are cultural constructions of female behavior that shape the so-called normal women in society. Russo calls such behavior "masquerade of the feminine," (216) which for her is what makes a female protagonist grotesque. The artificial construction of female behavior and appearance is linked to the meaning of the word "masquerade," which refers to people behaving as actors, displaying false behavior and appearances according to the role they have to enact in the society to which they belong. In Russo's theorization there is a clear connection between the feminine masquerade and the grotesque body. She bases her arguments on Bakhtin's theory of the grotesque body, which, according to him, is directly opposed to the classic, idealized body of normality (219).

Being grotesque, in the eyes of Western society, can be the only weapon that some female protagonists find to free themselves from the straightjacket of the female roles that are dictated by the ones in power. In simple terms, a grotesque 
image does not necessarily relate to patterns of destruction or negativity. The grotesque may be the only means for a protagonist's salvation. A good example is Stephen King's protagonist Dolores Claiborne, in which she says: "Sometimes you have to be a high-riding bitch to survive. Sometimes being a bitch is all a woman has to hang on to." 1 Dolores represents only one of the many facets that the grotesque may display in art and literature.

The multifaceted grotesque images that women, and men as well, may portray is also a crucial turning point that Atwood presents in her work. The grotesque in The Edible Woman has specific characteristics. In Atwoodian novels the stereotypical representations of beauty standing for good and the grotesque for evil are very often inverted. Atwood breaks with the social conventions of gender representations and also with grotesque representations. The grotesque in her work, whether in the protagonist's body, images or behavior, represents, very often, a positive experience. It is by being grotesque that some of the Atwoodian protagonists find absolution: a chance of rebirth from a symbolic death.

The narrative of The Edible Woman revolves around Marian MacAlpin, a woman who has just graduated, works as an interviewer for a food company, and has a handsome boyfriend named Peter Wollander. Peter has a Prince Charming image as he is physically well built, makes a good deal of money as a lawyer, and displays the stereotypical behavior of a gentleman. Contrasting with Peter there is Marian's lover, Duncan, whose body resembles "a cadaver" (Atwood 48). He is an undergraduate student, his eating habits are unhealthy and his behavior corrupts the image of a successful man. In the narrative, the love triangle, Marian-Peter-Duncan, is represented by doll figures that indicate their posture in society. The closer Marian gets to her marriage with Peter, the more she resembles a Barbie-doll, whose function is to be an object in the hands of men. Peter is also compared to a doll that Marian has on top of her dresser that is made of rubber, has a synthetic sme11, and is washable (Atwood 103). Peter resembles Ken, from the Barbie-doll collection, in that he has an impeccable appearance and embodies the image of the perfect man; one that most women would like to have as a husband. In contrast, Duncan is compared to an old doll, also on Marian's dresser, that has sawdust stuffing, worn-out clothes and peeling skin. Duncan is the one who refuses to be a replication of male perfection 


\section{EMTESE}

Belo Horizonte, v. 8, p. I-243, dez. 2004

and goes in search of his own identity in a world that bolsters standardized icons of perfect appearance. Marian gradually understands that Duncan is showing, through his grotesque body and behavior, that there are other options open to her, and that she can refuse to be an imitation of what society considers female perfection. Such societal demands do not correspond to her own identity but to a constructed world in which the female body becomes an object of desire.

Marian's body displays, through the course of the narrative, the kind of illness that prevents her from eating, that doctors would characterize as anorexia nervosa. The more Marian accepts the imposed female roles of perfection that shape her into a doll figure, the more her body rejects food. Marian gradually begins to reject al1 the food-groups, meat, vegetables, dairy, pasta, until she stops eating altogether. Her mind does not understand why her body is rejecting food. By doing so, Marian's body is actually telling her not to surrender to a world of consumerism and sexism in which women are a product of consumption. Peter portrays the image of an eater and Marian somehow does not understand that she is going to annihilate her own self if she submits to Peter. Peter, who patronizes her, would make her submit to an infantilized position in society, in which men give the orders and women passively accept them.

Peter has a collection of pens, pencils, cameras, guns and hunting knives that serve as phallic symbols, displayed in the narrative to show his power in society (Atwood 59). Marian feels threatened every time she listens to Peter telling his hunting stories to his friends and also when he forces her to strike poses for him to take pictures of her body near his possessions, such as his guns and hunting-knives. What her mind understands simply as Peter taking an innocent picture of her, Marian's body understands as Peter being abusive and dominating her. As a sort of warning to herself, Marian's body starts to display anorexic problems and restricts her eating habits.

The narrative culminates with Marian's refusal to be a victim in a world that shapes women's behavior. Marian bakes a woman-shaped cake, which stands for all the women who surrender to the artificial conduct that the so-called perfect women should follow, and cannibalizes it in front of Peter. Peter understands Marian's deed as grotesque and runs away because he does not want a woman who is not 
submissive to his powerful image. On the other hand, Duncan cannibalizes the womanshaped cake together with Marian, who finally understands that, by accepting the imposed rules of female perfection, she was annihilating her own identity. This identity is of a woman who no longer wants to be manipulated by stereotypical rules of female perfection and is in search of her freedom in a world that imprisons women in what Betty Friedan calls "a comfortable concentration camp" (282).

In several occasions, Atwood uses the grotesque in order to deconstruct and confront such rules of female perfection that demand from a woman passivity toward men. As a reference to Miles's characterizations of the grotesque, for example, through the narrative, the novel caricaturizes maternity and marital life by comparing Marian's friend to a snake who has swallowed a watermelon (Atwood 31) and, comparing Marian to a chocolate as she leaves the beauty parlor (Atwood 210), and displaying Peter's words as having "no specific shape or flavor" (Atwood 228). When analyzing other female bodies, Marian focuses only on the scatological aspects such as bodily fluids, varicose veins and vomit. Marian also sees her female colleagues as having a submissive and inferior position in their job and displaying artificially constructed bodies in which they would look amputated without nail polish or make-up. The novel runs its course with a strong image of inversion. Marian switches position from a victimized person into a powerful woman. Cannibalizing the woman-shaped cake is Marian's grotesque deed in which it shows the men in question that she no longer belongs to a consumerist world in which women are submissive.

Finally, I would consider the image of cannibalism in the end of the novel as grotesque. The woman-shaped cake is a riddle to Peter and Duncan as much as the sphinx is to 0edipus. The sphinx eats the ones who do not solve the riddle she proposes. After Marian understands what her roles in society are, she symbolically eats the images into which she does not want to imprison herself. Peter runs away from it, but Duncan, like Oedipus, manages to solve the riddle.

The Edible Woman is full of riddles to be solved. In the Atwoodian way of portraying the grotesque, appearance is deceiving. Marian gets rid of her masks and lives her life learning to respect herself. Through the grotesque image of the woman-shaped cake, Marian follows the positive method that Kayser suggests: she 


\section{EM TESE}

Belo Horizonte, v. 8, p. I-243, dez. 2004

evokes the grotesque only to undermine it. From this experience, Marian uses the grotesque to acquire knowledge of herself, to become aware of the rules of the world around her, to free herself from old concepts of female behavior and to search for new possibilities in life.

NOTA:

1 KING, Stephen. Dolores Claiborne. Dir. Taylor Hackford. Perf. Kathy Bates, Jennifer Jason Leigh, Judy Parfitt and Christopher Plummer. 1995. DVD, Castle Rock Entertainment and Warner Bros., 2002.

ABSTRACT :

This article studies grotesque aspects of Margaret Atwood's The Edible Woman, focusing on the contrasts of stereotypes of perfection and imperfection, gender roles, and the protagonist's rebellion against society's imposition of female behavior.

KEY WORDS: the grotesque, Canadian Literature, Gender Studies.

REFERÊNCIAS BIBLIOGRÁFICAS

ADAMS, James Luther; YATES, Wilson (Ed.). The Grotesque in Art \& Literature: Theological Reflections. Grand Rapids, Michigan: William B. Erdmans, 1997.

ATW00D, Margaret. The Edible Woman. London: Virago, 1999.

BAKHTIN, Mikhail. Rabelais and His World. Trans. Helene Iswolsky. Cambridge: MIT Press, 1968.

FRIEDAN, Betty. The Feminine Mystique. New York: Laurel, 1984 .

HARPHAM, Geoffrey Galt. On the Grotesque: Strategies of Contradiction in Art. Princeton, N. J.: Princeton UP, 1982.

HOWELLS, Coral Ann. Modern Novelists: Margaret Atwood. London: Macmillan Press, 1996.

KAYSER, Wolfgang. The Grotesque in Art and Literature. Trans. Ulrich Weisstein. New York: Columbia UP, 1981.

KING, Stephen. Dolores Claiborne. Dir. Taylor Hackford. Perf. Kathy Bates, Jennifer Jason Leigh, Judy Parfitt and Christopher Plummer. 1995. DVD, Castle Rock Entertainment and Warner Bros., 2002. 
MILES, Margaret. "Carnal Abominations: The Female Body as Grotesque." The Grotesque in Art and Literature: Theological Reflections. LUTHER, James Adams; YATES, Wilson (Ed.). Grand Rapids, Michigan: William B. Eerdmans, 1997. 83-112.

RUSSO, Mary. "Carnival and Theory." Feminist Studies/ Critical Studies. LAURETIS, Teresa de (Ed.). Bloomington: Indiana UP, 1986. 213-29. 